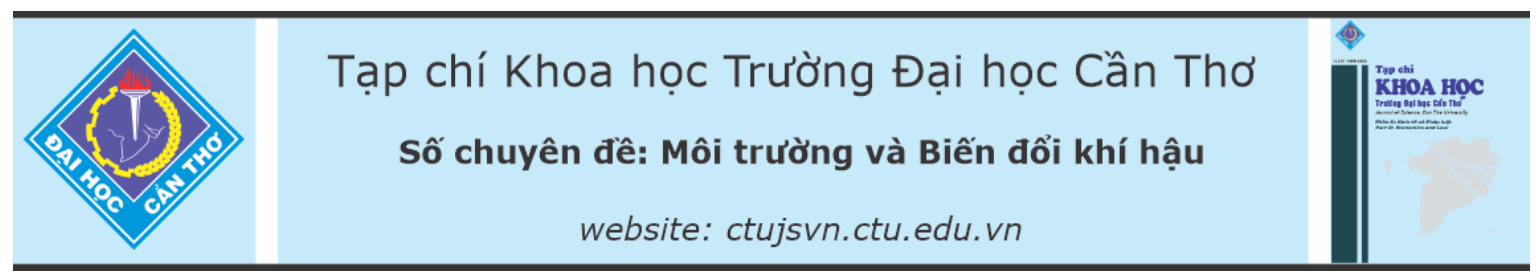

DOI:10.22144/ctu.jsi.2021.029

\title{
ĐÁNH GIÁ ĐÔ PHÌ NHIÊU ĐẤT CANH TÁC LÚA TRONG VÀ NGOÀI ĐÊ BAO NGĂN LŨ Ở NHÓM ĐẤT CÓ VẤN ĐỀ CỦA TỈNH AN GIANG
}

\author{
Trần Bá Linh ${ }^{1 *}$, Trần Sỹ Nam², Huỳnh Công Khánh ${ }^{2}$, Lâm Văn Hậu ${ }^{3}$ và Mitsunori Tarao ${ }^{4}$ \\ ${ }^{1}$ Khoa Nông nghiệp, Truoòng Đại học Cần Tho' \\ ${ }^{2}$ Khoa Môi trường và Tài nguyên thiên nhiên, Truờng Đại học Cần Thơ \\ ${ }^{3}$ Sở Khoa họ và Công nghệ tỉnh An Giang \\ ${ }^{4}$ Tokyo University of Agriculture and Technology

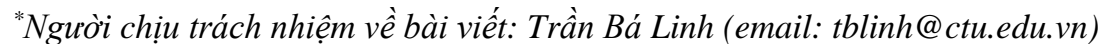

\section{Thông tin chung:}

Ngày nhận bài: $12 / 04 / 2021$

Ngày nhận bài sủa: 04/10/2021

Ngày duyệt đăng: 15/11/2021

\section{Title:}

Assessing fertility of problem soils inside and outside the full dike system used for rice cultivation in An Giang province

\section{Tù khóa:}

Đất phèn, đất phù sa cổ, đê bao, hóa hoc đất, vật lý đất

\section{Keywords:}

Acid sulfate soil, degraded soil, dike, soil chemistry, soil physics

\begin{abstract}
The study was carried out with the aim of assessing the physical and chemical properties of soil inside and outside the dike system control flood in the acid sulphate soil at Tri Ton and degraded soil at Tinh Bien. The number of samples randomly collected per soil group was 32 samples, including: 16 samples inside the dike (3-crop rice area) and 16 samples outside the dike (2crop rice). The results showed that cultivation three rice crops per year inside the dike caused the soil pH lower than the soil pH outside the dike; the EC of the soil inside the dike is higher than the EC of the soil outside the dike. The organic matter content of topsoil horizon ( $A p)$ in the inside the dike ( 3 rice crops/year) is higher than that in outside the dike (2 rice crops/year). As a result, cation exchange capacity (CEC), the total nitrogen of the soil inside the dike is higher than that in the outside the dike, especially in the surface layer (Ap). Meanwhile, total phosphorus and total potassium content did not show a statistically significant difference between inside and outside the dike in both study sites. The soil compaction of Bg horizon was higher than that in inside the dike compared to outside the dike in both Tri Ton and Tinh Bien study sites, expressed by low soil porosity and soil permeability, high bulk density and soil penetration resistance.
\end{abstract}

\section{TÓM TẮT}

Đề tài nghiên cứu được thưc hiện nhằm muc tiêu đánh giá tính chất vật lý, hóa hoc đất trong và ngoài đê bao ngăn lũ ở nhóm đất phèn ở Tri Tôn và đất phù sa cổ ở Tịnh Biên. Số lương mẫu đất được thu ngẫu nhiên trên mỗi nhóm đất là 32 mấu gồm: 16 mẫu trong đê (vùng lúa 3 vu) và 16 mẫu ngoài đê (lúa $2 v u$ ). Kết quả nghiên cứu cho thấy việc canh tác lúa 3 vu trong đê bao đã làm $p H$ đất trong đê thấp hơn so với $p H$ đất ngoài đê; $E C$ của đất trong đê cao hơn so với EC của đất ngoài đê. Hàm lương chất hữu cơ tầng mặt trong đê (3 vu lúa) cao hơn so với đất ngoài đê (2 vu lúa). Tù đó dẫn đến khả năng trao đổi cation (CEC), đạm tổng số của đất trong đê cũng cao hơn so với đất ngoài đê, đặc biệt ở tầng đất mặt Ap. Trong khi đó, hàm lượng lân tổng số và kali tổng số khác biệt không có ý nghĩa thống kê ở cả hai điểm nghiên cưu. Độnén dẽ của tầng đất Bg luôn cao hơn ở đất trong đê so với đất ngoài đê ở cả hai điểm nghiên cưu Tri Tôn và Tịnh Biên thể hiện qua độ xốp và hệ số thấm thấp, dung trọng và độ chặt của đất cao. 


\section{GIỚI THIỆU}

An Giang là tỉnh đầu nguồn ở Đồng bằng sông Cửu Long, hằng năm chịu tác động của lũ rất lớn. Mặc dù mùa lũ được xem là lợi thế cho sản xuất nông nghiệp, nhưng việc hình thành đê bao đã phát triển ở nhiều nơi trong vùng ngập lũ của tỉnh $\mathrm{An}$ Giang. Hệ thống đê bao được xây dựng với mục tiêu kiểm soát lũ nhằm hạn chế thiệt hại về người và của, ổn định cuộc sống và gia tăng sản xuất (Nguyễn Xuân Thịnh và ctv., 2016). Tuy nhiên, ngoài những lợi ích của đê bao, các công trình này đã ngăn cản lượng phù sa tích lũy trên đồng ruộng và lượng nước trao đồi giữa đồng ruộng và môi trường bên ngoài (Dương Quỳnh Thanh và ctv., 2017; Phạm Lê Mỹ Duyên \& Văn Phạm Đăng Trí, 2015). Thực tế, do tăng vụ liên tục và việc đê bao khống chế lũ đã khiến đất đai bị suy thoái, sâu bệnh luôn có môi trường tồn tại và phát triển. Vì thế, để duy trì năng suất cây trồng, người dân phải gia tăng khối lượng phân bón hóa học và thuốc trừ sâu, đây là một trong những nguyên nhân gây ô nhiễm nguồn nước mặt trong kênh nội đồng (Le et al., 2006). Trước đây, đã có những nghiên cứu về đánh giá động thái dinh dưỡng-độ phì của đất và ảnh hưởng của việc kiểm soát lũ lên sức sản xuất của đất trong vùng đê bao khép kín của Nguyễn Hữu Chiếm và Huỳnh Công Khánh (2016), Nguyễn Hữu Chiếm và ctv. (2017); đánh giá chất lượng đất và phù sa trong và ngoài đê bao ở Chợ Mới và Phú Tân tỉnh An Giang của Dương Hồng Gấm (2015). Hầu hết các nghiên cứu đều cho rằng sản xuất lúa nhiều vụ trong năm sẽ giảm độ phì nhiêu của đất, tăng lượng phân bón cho cây lúa nhưng năng suất không tăng, do sự suy giảm chất hữu cơ, đất bị nén dẽ dẫn đến cây trồng khó hấp thu các chất dinh dưỡng. Ngoài ra, việc bao đê canh tác lúa 3 vụ còn làm giảm lượng phù sa bồi đắp cho đồng ruộng hàng năm làm thay đổi các điều kiện tự nhiên cũng như các đặc tính lý - hóa học trong môi trường đất. Đồng thời, sản xuất lúa 3 vụ trong đê bao bộc lộ một số mặt hạn chế, tiêu cực về môi trường, nguồn nước tù đọng ô nhiễm vì phú dưỡng hóa từ phân bón hóa học và nhiễm độc vì các loại nông dược.

Đất phèn có tên theo phân loại của FAO là Thionic Gleysols, là tên gọi dùng để chỉ nhóm đất mà tiến trình hình thành sản sinh ra lượng sulphuric acid ảnh hưởng lâu dài đến đặc tính chủ yếu của đất (Mohr et al., 1972). Đất phèn là đất chứa nhiều gốc sunphat $\left(\mathrm{SO}_{4}{ }^{2-}\right)$ và có $\mathrm{pH}$ thấp. Đất phèn ở An Giang phân bố nhiều ở vùng tiếp giáp với tỉnh Kiên Giang, thuộc địa phận huyện Tri Tôn. Nhóm đất phù sa cổ tên theo phân loại của FAO là Plinthosols. Đất phù sa cổ nghè̀ dinh dưỡng và độ thoát thủy, tơi xốp kém. Đất phù sa cổ chủ yếu phân bố ở 2 huyện Tri Tôn và Tịnh Biên. Chúng hình thành nên dãy đồng bằng quanh núi như khu vực quanh núi Dài, núi Cấm, cánh đồng ven kênh Vĩnh Tế giáp biên giới Campuchia (Bộ môn Khoa học đất, 2015).

Hiện tại, các nghiên cứu đánh giá một cách đầy đủ về các đặc tính lý, hóa học của môi trường đất canh tác lúa trong và ngoài đê bao ở vùng đất phèn và đất phù sa cổ là chưa có. Đây là những nhóm đất có vấn đề gây nhiều trở ngại cho sản xuất nông nghiệp so với các nhóm đất khác. Do đó, đề tài được thực hiện nhằm đánh giá độ phì nhiêu đất canh tác lúa trong và ngoài hệ thống đê bao ngăn lũ trên đất phèn và đất phù sa cổ hướng đến nền sản xuất nông nghiệp bền vững hơn trong tương lai.

\section{PHƯƠNG PHÁP NGHIÊN CÚU}

\section{1. Địa điểm nghiên cứu}

Nghiên cứu được thực hiện tại 2 khu vực đại diện cho nhóm đất phèn và nhóm đất phù sa cổ như sau: (1) ruộng đang canh tác lúa trong và ngoài đê bao tại xã Lương An Trà, huyện Tri Tôn, (2) ruộng đang canh tác lúa trong và ngoài đê bao tại xã An Nông, huyện Tịnh Biên. Khu vực trong đê bao là vùng sản xuất lúa 3 vụ lúa/năm và khu vực ngoài đê bao là vùng sản xuất 2 vụ lúa/năm (Hình 1). 


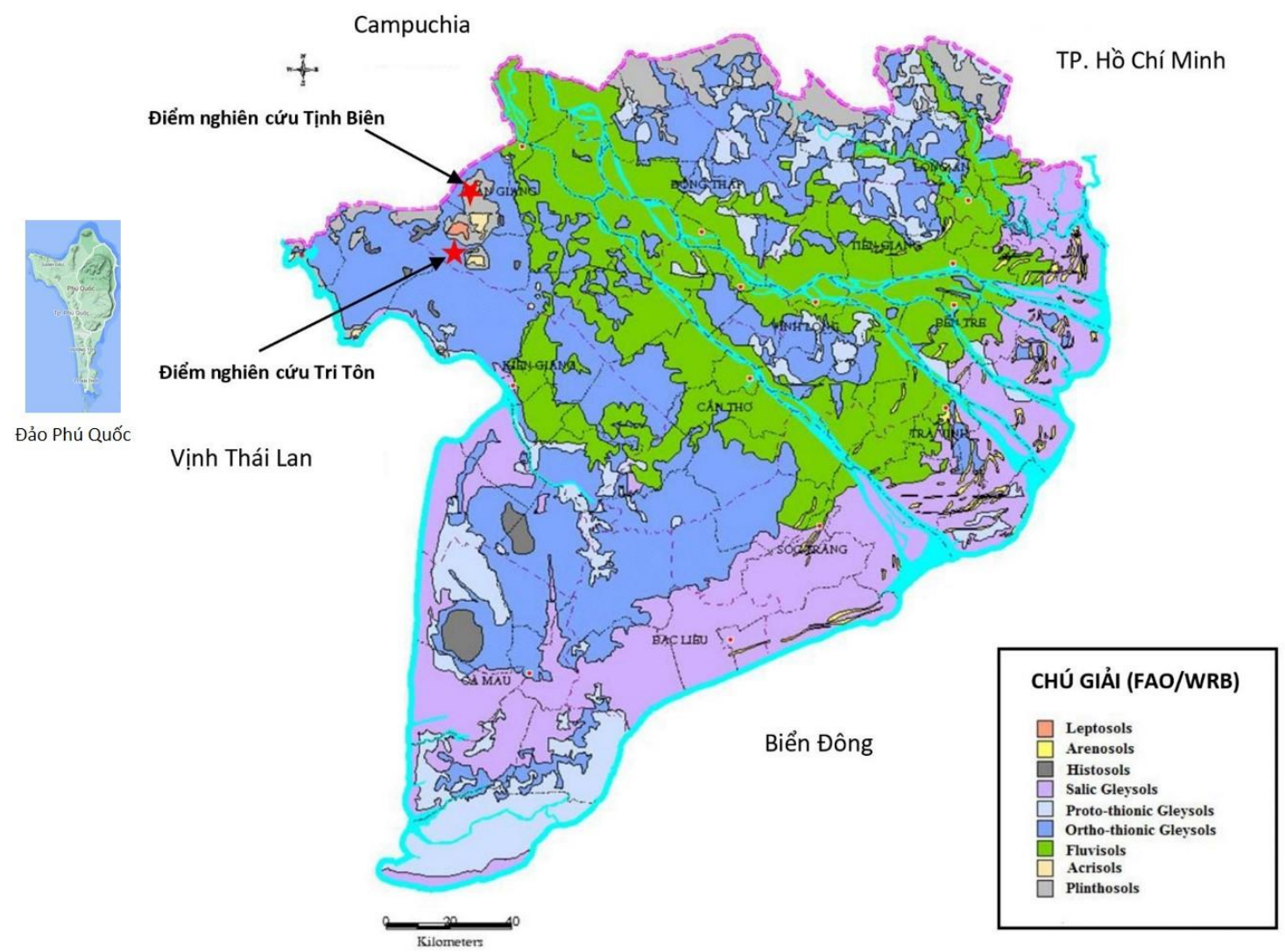

\section{Hình 1. Bản đồ vị trí nghiên cứu Tri Tôn và Tịnh Biên}

\subsection{Phương pháp nghiên cứu}

Dựa trên bản đồ đất của Bộ môn Khoa học đất, Trường Đại học Cần Thơ (2015) tiến hành khoan khảo sát phẫu diện thực tế theo hướng dẫn của $\mathrm{FAO} / \mathrm{UNESCO}$ để xác định và phân loại nhóm đất nghiên cứu. Nhóm đất nghiên cứu tại Tri Tôn được xác định là Thionic Gleysols (đất phèn) và nhóm đất nghiên cứu tại Tịnh Biên là Haplic Plinthosols (đất phù sa cổ).

Mẫu đất được thu sau khi nước lũ rút (cuối vụ Thu Đông 2019 - Bảng 2) và thu ngẫu nhiên trên mỗi nhóm đất là 32 mẫu gồm: 16 mẫu trong đê (vùng lúa 3 vụ) và 16 mẫu ngoài đê (lúa 2 vụ). Mỗi ruộng đất được thu ở 2 tầng (tầng $\mathrm{Ap}: 0-15 \mathrm{~cm}$ và tầng $\mathrm{Bg}$ : $15-30 \mathrm{~cm}$ ). Mẫu đất được lấy theo phương pháp mô tả trong Sổ tay phân tích đất - nước phân bón cây trồng của Viện Thổ nhưỡng nông hóa (1998) và theo phương pháp chuẩn đang áp dụng tại phòng thí nghiệm khoa Nông nghiệp - Trường Đại học Cần Thơ. Mẫu đất nguyên thủy được lấy bằng ông ring hình trụ có thể tích là $98,125 \mathrm{~cm}^{3}$. Mẫu đất xáo trộn được lấy bằng khoan máng ngắn trên nhiều điểm ngẫu nhiên sau đó trộn lại và lấy khoảng 2 $\mathrm{kg} / \mathrm{mẫu}$. Mẫu sau khi thu được cho vào túi polyethylene, ghi ký hiệu mẫu, địa điểm. Toàn bộ các mẫu đất sau khi thu được mang về phòng thí nghiệm Bộ môn Khoa học đất - Khoa Nông nghiệp tiến hành phơi khô với nhiệt độ phòng. Mẫu đất sau khi phơi khô loại bỏ sỏi đá và xác bả thực vật, vỏ ốc..., sau đó tiến hành nghiền mịn và qua rây để tiến hành phân tích.

\subsection{Phương pháp phân tích mẫu}

Các thông số phân tích đất gồm: Thành phần cơ giới, dung trọng, tỉ trọng, độ xốp, hệ số thấm bão hòa, đô chặt của đất, $\mathrm{pH}, \mathrm{EC}, \mathrm{CEC}$, chất hữu cơ, đạm tổng số, lân tổng số, kali tổng số. Phương pháp phân tích đất được trình bày tại Bảng 1 . 


\section{Bảng 1. Các thông số và phương pháp phân tích đất}

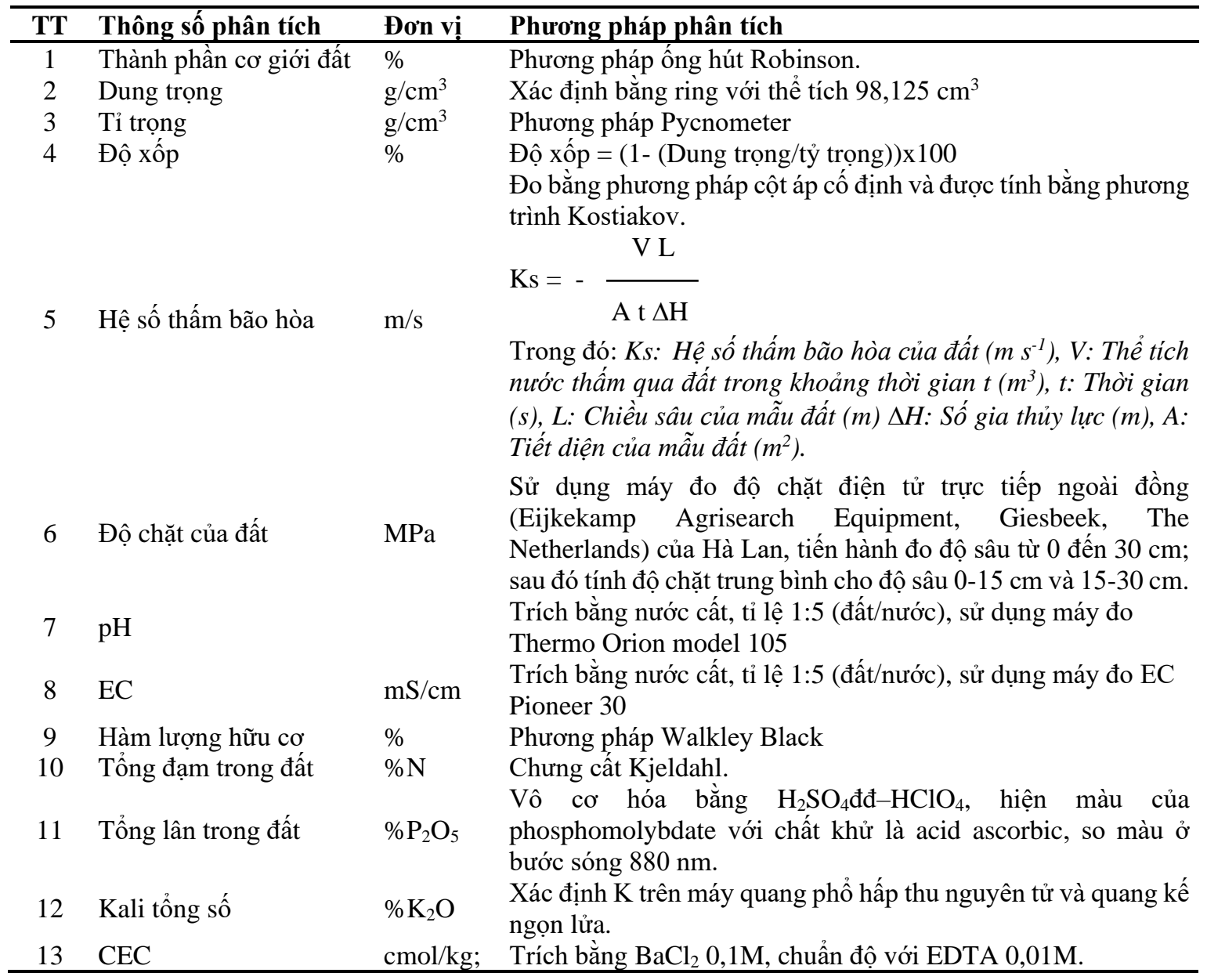

\subsection{Phương pháp xử lý số liệu}

Các số liệu được tính toán và xử lý bằng phần mềm Microsoft Excel 2016, vẽ đồ thị bằng phần mềm SigmaPlot 14.0. Thực hiện phân tích thống kê kiểm định Independent Samples T-Test mức ý nghĩa $5 \%$ để so sánh các thông số về tính chất lý hóa học đất giữa trong và ngoài đê bao, giữa tầng $\mathrm{Ap}$ và tầng $\mathrm{Bg}$ trong cùng hệ thống canh tác bằng phần mềm thống kê IBM SPSS 20.0.

\section{KÊT QUẢ VÀ THẢO LUẬn}

\subsection{Lịch thời vụ canh tác lúa tại vùng nghiên cứu}

Cơ cấu mùa vụ tại 2 khu vực nghiên cứu (Bảng
Xuân: Xuống giống khoảng giữa tháng 12 , thu hoạch vào khoảng giữa tháng 03 ; (2) Vụ Hè Thu: Xuống giống vào khoảng giữa tháng 04 , thu hoạch vào khoảng cuối tháng 07 ; (3) Vụ Thu Đông: Xuống giống vào khoảng giữa tháng 08 , thu hoạch vào khoảng giữa tháng 11 . Tương tự, khu vực canh tác lúa 2 vụ cũng có cơ cấu vụ Đông Xuân và vụ Hè Thu với lịch xuống giống được trình bày trong Bảng 1 . Tuy nhiên, khu vực này không canh tác vụ lúa Thu Đông (vụ 3 ) vì trong những tháng này, nước lũ tràn về làm đồng ruộng ngập sâu nên không thể canh tác lúa.

Bảng 2. Lịch thời vụ 2 vùng nghiên cứu Tri Tôn và Tịnh Biên

\begin{tabular}{lllllllllllll}
\hline Tháng (Dương lịch) & 12 & $\mathbf{1}$ & $\mathbf{2}$ & $\mathbf{3}$ & $\mathbf{4}$ & $\mathbf{5}$ & $\mathbf{6}$ & $\mathbf{7}$ & $\mathbf{8}$ & $\mathbf{9}$ & $\mathbf{1 0}$ & 11 \\
\hline Đông - Xuân & & & & & & & & & & & & \\
Hè - Thu \\
Thu - Đông
\end{tabular}




\subsection{Tính chất vật lý đất trong và ngoài đê bao}

\subsubsection{Thành phần co giới đất}

Kết quả phân tích thành phần cơ giới tầng mặt 0 $15 \mathrm{~cm}$ của đất được trình bày ở Hình 2 cho thấy đất ở ngoài đê của Tri Tôn có tỷ lệ cát là $2,28 \%$, thịt $38,29 \%$ sét là $59,44 \%$; đất ở trong đê có tỷ lệ cát là $3,48 \%$, thịt $39,8 \%$ sét là $56,73 \%$. Theo tam giác sa cấu đất của USDA (1975), đất ở trong và ngoài đê của Tri Tôn được phân loại là đất sét. Tỷ lệ sét trong đê có xu hướng cao hơn ngoài đê, nhưng $\%$ thịt và $\%$ cát ngoài đê lại có xu hướng cao hơn trong đê nhưng khác biệt không có ý nghĩa thống kê. Kết quả này phù hợp với nghiên cứu của Phạm Ngọc Xuân (2004) cho rằng thành phần cơ giới trong đất khu đê bao khép kín có tỷ lệ sét cao và phần trăm thịt thấp hơn so với khu ngoài đê bao, do phù sa có hàm lượng thịt cao không được bồi đắp ở khu vực bao đê.

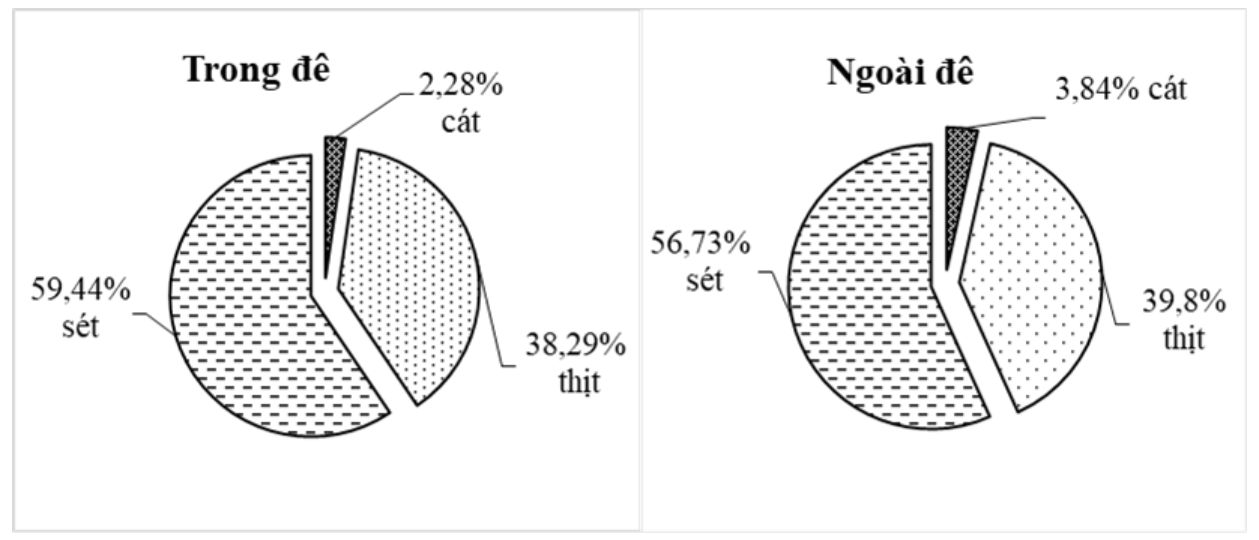

Hình 2. Thành phần cơ giới đất trong và ngoài đê tại điểm nghiên cứu Tri Tôn

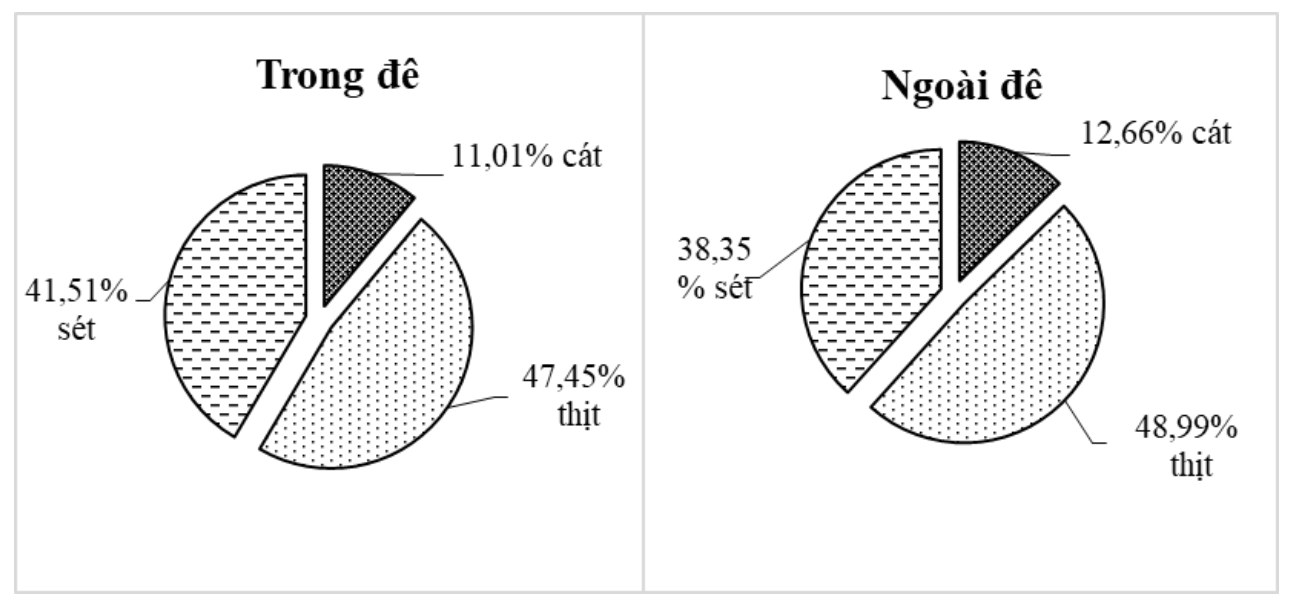

Hình 3. Thành phần cơ giới đất trong và ngoài đê tại điểm nghiên cứu Tịnh Biên

Kết quả nghiên cứu cho thấy (Hình 3 ) đất phù sa cổ Tịnh Biên trong đê có tỷ lệ cát là $11,01 \%$, thịt là $47,45 \%$ và $\%$ sét là $41,51 \%$. Theo tam giác sa cấu đất của USDA (1975), đất ở trong đê được phân loại là đất sét pha thịt. Đất ở ngoài đê có $\%$ cát là $12,66 \%$, $\%$ thịt là $48,99 \%$ và $\%$ sét là $38,35 \%$ và được phân loại là đất thịt trung bình pha sét (USDA, 1984). Kết quả nghiên cứu cho thây tương tự Tri Tôn, \% sét trong đê ở Tịnh Biên cao hơn ngoài đê, nhưng \% cát và $\%$ thịt ngoài đê lại cao hơn trong đê. Ở vùng ngoài đê, thành phần đất thịt có xu hướng cao hơn vùng trong đê, điều này có thể lý giải là trầm tích chứa nhiều cấp hạt thịt ngoài đê cao hơn trong đê.

\subsubsection{Dung trọng của đất}

Kết quả phân tích dung trọng đất được trình bày ở Hình 4 cho thấy giá trị dung trọng đất tại Tri Tôn ở tầng $0-15 \mathrm{~cm}(\mathrm{Ap})$ trong và ngoài đê lần lượt là $0,91 \mathrm{~g} / \mathrm{cm}^{3}$ và $0,99 \mathrm{~g} / \mathrm{cm}^{3}$; trong khi đó dung trọng đất tầng $15-30 \mathrm{~cm}(\mathrm{Bg})$ trong và ngoài đê lần lượt là $1,34 \mathrm{~g} / \mathrm{cm}^{3}$ và $1,17 \mathrm{~g} / \mathrm{cm}^{3}$. Cả 2 tầng đều có sự khác biệt có ý nghĩa thống kê $(\mathrm{p}<0,05)$ giữa dung trọng đất trong đê và ngoài đê. 


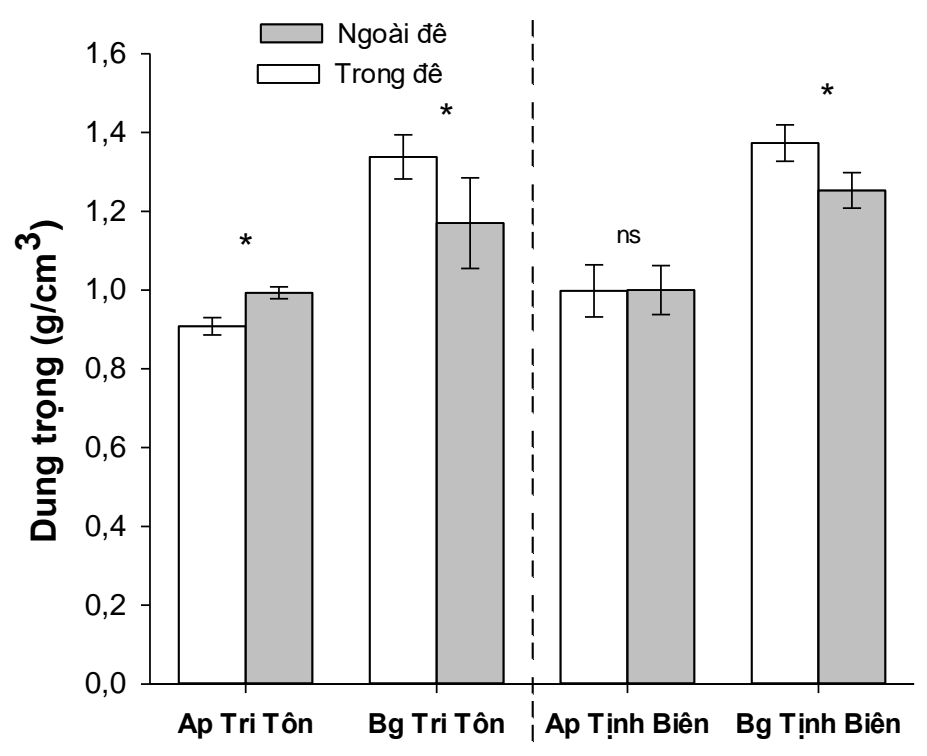

Hình 4. Dung trọng đất trong và ngoài đê bao tại Tri Tôn và Tịnh Biên

Ghi chú: "*” khác biệt có ý nghĩa thống kê mức 5\%, "ns" khác biệt không có ý nghĩa thống kê.

Kết quả nghiên cứu, giá trị dung trọng tại Tịnh Biên ở tầng $\mathrm{Ap}$ giữa trong và ngoài đê khác biệt không có ý nghĩa thống kê ( $\mathrm{p}>0,05)$; tầng $B g$ trong và ngoài đê lần lượt là $1,37 \mathrm{~g} / \mathrm{cm}^{3}$ và $1,25 \mathrm{~g} / \mathrm{cm}^{3}$, và khác biệt có ý nghĩa thống kê, giá trị dung trọng tầng $\mathrm{Bg}$ cao hơn tầng $\mathrm{Ap}$ rõ rệt $\left(0,31 \mathrm{~g} / \mathrm{cm}^{3}\right)$. Theo Cass (1999), đất tầng Ap của Tri Tôn và Tịnh Biên là đất không bị nén dẽ, thích hợp cho cây trồng phát triển; còn tầng $\mathrm{Bg}$ của Tri Tôn và Tịnh Biên là đất bị nén dẽ gây khó khăn cho sự phát triển của rễ cây trồng và ảnh hưởng đến việc hấp thu chất dinh dưỡng. Giá trị dung trọng của tầng $\mathrm{Bg}$ trong đê cao hơn ngoài đê được giải thích là do canh tác 3 vụ nên máy móc làm đất và thu hoạch di chuyển trên mặt ruộng nhiều hơn nên làm cho đất trong đê của vùng 3 vụ bị nén dẽ nhiều hơn vùng 2 vụ. Theo Nguyễn Thế Đặng và Nguyễn Thế Hùng (1999), nếu dung trọng đất >1,2 $\mathrm{g} / \mathrm{cm}^{3}$ thì việc canh tác gặp khó khăn, năng suất cây trồng bị ảnh hưởng do đất bị nén dẽ, làm ngăn cản sự phát triển của bộ rễ. Đất có dung trọng thích hợp nhất cho cây là $1,0-1,1 \mathrm{~g} / \mathrm{cm}^{3}$, nên dung trọng đất trong và ngoài đê ở tầng $\mathrm{Ap}$ thích hợp cho cây lúa phát triển.

\subsubsection{Tỷ trọng của đất}

Kết quả nghiên cứu cho thấy giá trị tỷ trọng tầng $A p$ và tầng $B g$ trong đê và ngoài đê của cả hai điểm nghiên cứu Tri Tôn và Tịnh Biên khác biệt không có ý nghĩa thống kê $(p>0,05)$. Giá trị tỷ trọng trung bình trong và ngoài đê tại Tri Tôn của tầng $\mathrm{Ap}$ là 2,39 $\mathrm{g} / \mathrm{cm}^{3}$, tầng $\mathrm{Bg}$ là $2,52 \mathrm{~g} / \mathrm{cm}^{3}$ và giá trị tỷ trọng trung bình tại Tịnh Biên của tầng $\mathrm{Ap}$ là $2,42 \mathrm{~g} / \mathrm{cm}^{3}$ và 2,47 $\mathrm{g} / \mathrm{cm}^{3}$. Tỷ trọng tầng $\mathrm{Bg}$ luôn lớn hơn tầng $\mathrm{Ap}$ (Hình 5). Theo thang đánh giá tỷ trọng của Karchinski (1965) được trích dẫn bởi Trần Thành Lập (1999), tầng đất $\mathrm{Bg}$ tại Tri Tôn $>2,5 \mathrm{~g} / \mathrm{cm}^{3}$ có lượng mùn trung bình; các tầng còn lại có trung bình tỷ trọng < $2,5 \mathrm{~g} / \mathrm{cm}^{3}$ nên đất các tầng này là đất có lượng mùn cao. Đất có nhiều chất hữu cơ và mùn thì tỷ trọng càng nhỏ. Ngoài hàm lượng chất hữu cơ, tỷ trọng của đất chủ yếu phụ thuộc vào thành phần khoáng vật và thành phần hóa học của đất. Các loại đất chính ở Việt Nam có tỷ trọng tầng đất mặt dao động từ 2,49 - 2,83 $\mathrm{g} / \mathrm{cm}^{3}$ (Viện Thổ nhưỡng Nông hóa, 2009). 


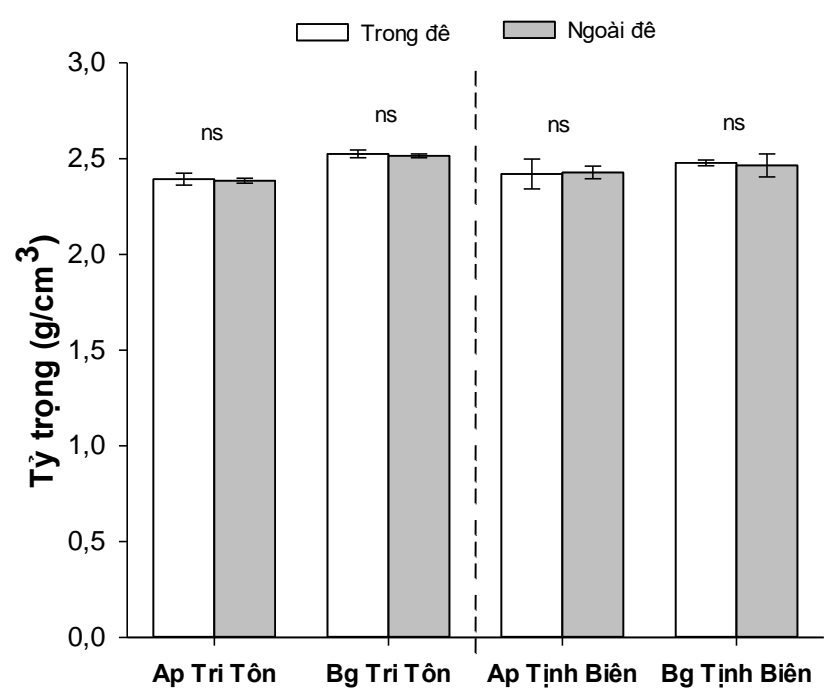

Hình 5. Tỷ trọng đất trong và ngoài đê bao tại Tri Tôn và Tịnh Biên

Ghi chú: “*” khác biệt có ý nghĩa thống kê mưc 5\%, "ns” khác biệt không có ý nghĩa thống kê.

\subsection{4. Độ xốp của đất}

Kết quả thống kê (Hình 6) cho thấy tại điểm nghiên cứu Tri Tôn có độ xốp đất tầng $\mathrm{Ap}$ trong và ngoài đê có sự khác biệt thống kê; tầng $\mathrm{Bg}$ trong và ngoài đê cũng có sự khác biệt thống kê $(\mathrm{p}<0,05)$. Theo đánh giá độ xốp của Cass (1999), tầng Ap có độ xốp cao; tầng $\mathrm{Bg}$ có độ xốp thấp, có nguy cơ bị nén dẽ.

Kết quả thống kê tại Tịnh Biên cho thấy độ xốp tầng $\mathrm{Ap}$ trong và ngoài đê lần lượt là $58,7 \%$ và
$58,8 \%$, khác biệt không có ý nghĩa thống kê $(\mathrm{p}>0,05)$; trong khi đó tầng $\mathrm{Bg}$ có độ xốp trung bình trong và ngoài đê lần lượt là $44,7 \%$ và $49,2 \%$ và khác biệt có ý nghĩa thống kê ở mức 5\%. Theo đánh giá độ xốp của Cass (1999), tầng Ap đất có độ xốp cao; tầng $\mathrm{Bg}$ có độ xốp thấp, có nguy cơ bị nén dẽ mạnh, đất kém thông thoáng có thể giới hạn sự phát triển của rễ, đặc biệt ảnh hưởng đến việc hấp thu chất dinh dưỡng (Lipiec \& Stepniewski, 1995).

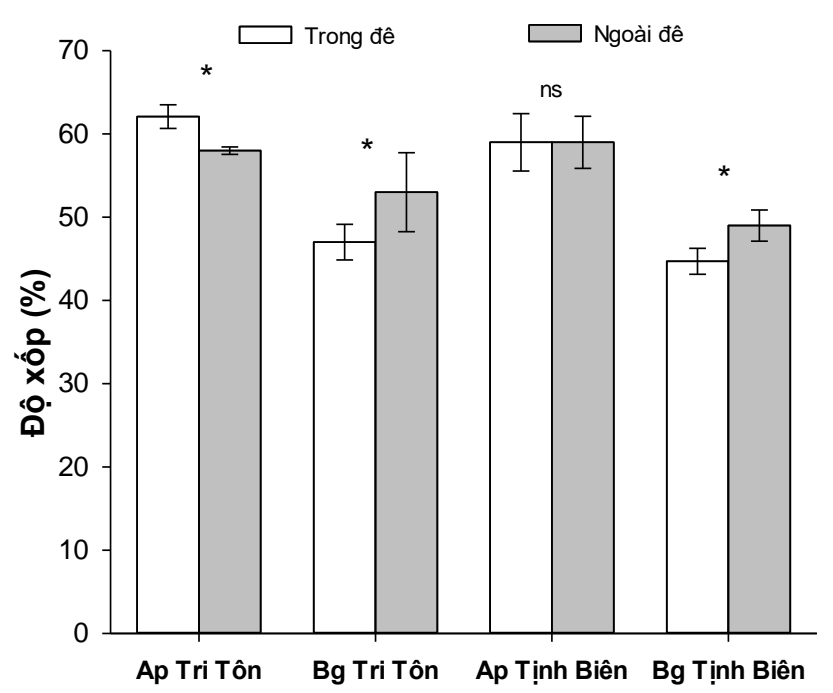

Hình 6. Độ xốp đất trong và ngoài đê bao tại Tri Tôn và Tịnh Biên

Ghi chú: “*” khác biệt có ý nghĩa thống kê mức 5\%, "ns" khác biệt không có ý nghĩa thống kê. 
Độ xốp của đất cần thiết cho sự phát triển của rễ cây trồng và sự di chuyển của nước cũng như không khí trong đất. Đất có độ xốp cao là điều kiện tốt cho cây trồng phát triển (Lê Văn Khoa, 2003; Swan et al., 1999). Tại 2 vị trí nghiên cứu, tầng mặt Ap có độ xốp cao, điều này là do người dân cày xới đất thường xuyên sau mỗi vụ canh tác đã làm cho độ xốp của đất được duy trì tốt. Tuy nhiên, tầng $\mathrm{Bg}$ của đất trong đê ở cả 2 điểm nghiên cứu có độ xốp thấp, đất bị nén dẽ mạnh. Do tầng $\mathrm{Bg}$ là tầng đế cày và việc làm đất mỗi vụ canh tác đã không cày xới đến tầng đất này. Thêm vào đó, máy móc cơ giới sử dụng trên ruộng nhiều hơn trong trường hợp mô hình canh tác 3 vụ lúa trong đê bao sẽ làm cho tầng $\mathrm{Bg}$ càng bị nén dẽ mạnh hơn.

\subsection{5. Độ chặt của đất}

Kết quả thống kê (Hình 7) cho thấy độ chặt của đất tại Tri Tôn ở tầng canh tác từ 0 đến $15 \mathrm{~cm}$ khác biệt không có ý nghĩa thống kê ( $p>0,05)$, trung bình giá trị độ chặt đất trong đê (lúa 3 vụ) và ngoài đê (lúa 2 vụ) lần lượt là $0,24 \mathrm{MPa}$ và $0,21 \mathrm{MPa}$. Nguyên

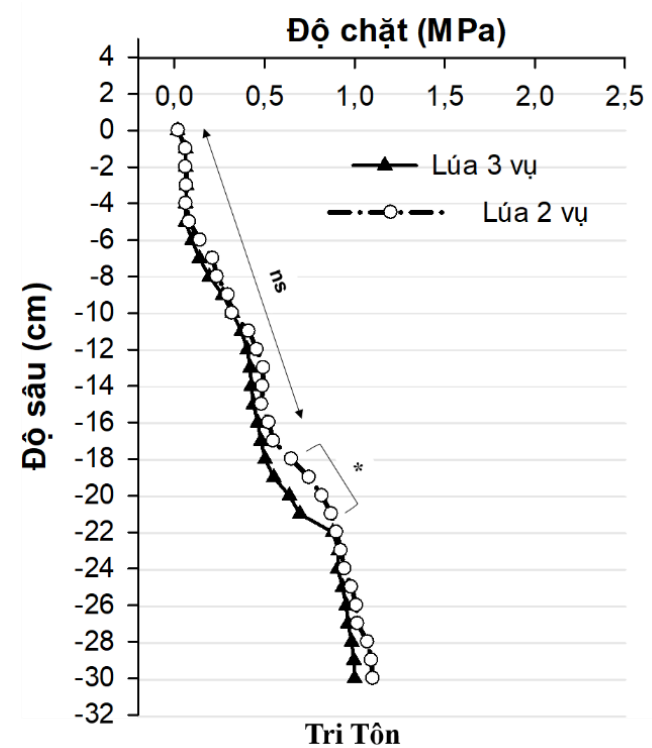

nhân không khác biệt có thể do tầng canh tác (Ap) cả 2 vùng trong và ngoài đê được cày xới, nông dân làm đất mỗi vụ canh tác nên độ chặt tầng này không khác biệt. Tuy nhiên, kết quả nghiên cứu độ chặt trung bình của đất vùng canh tác lúa 3 vụ và vùng canh tác lúa 2 vụ ở độ sâu từ $15 \mathrm{~cm}$ đến $30 \mathrm{~cm}$ lần lượt là $0,72 \mathrm{MPa}$ và $0,60 \mathrm{MPa}$, độ chặt trong đê cao hơn ngoài đê, khác biệt có ý nghĩa thống kê $(\mathrm{p}<0,05)$.

Kết quả nghiên cứu độ chặt của đất tại Tịnh Biên cho thấy ở tầng canh tác $(\mathrm{Ap})$ có độ sâu từ 0 đến 15 cm không có sự khác biệt thống kê, độ chặt trung bình của đất trong và ngoài đê lần lượt là $0,53 \mathrm{MPa}$ và $0,49 \mathrm{MPa}$. Tương tự đất Tri Tôn, nguyên nhân không có sự khác biệt là do đất tầng canh tác trong và ngoài đê đều được cày xới nên độ chặt tầng này không khác biệt có ý nghĩa thống kê. Trong khí đó, giá trị trung bình độ chặt ở độ sâu từ 15 đển $30 \mathrm{~cm}$ trong và ngoài đê lần lượt là $1,9 \mathrm{MPa}$ và $1,69 \mathrm{MPa}$, độ chặt trong đê cao hơn ngoài đê có ý nghĩa thống kê $(\mathrm{p}<0,05)$.

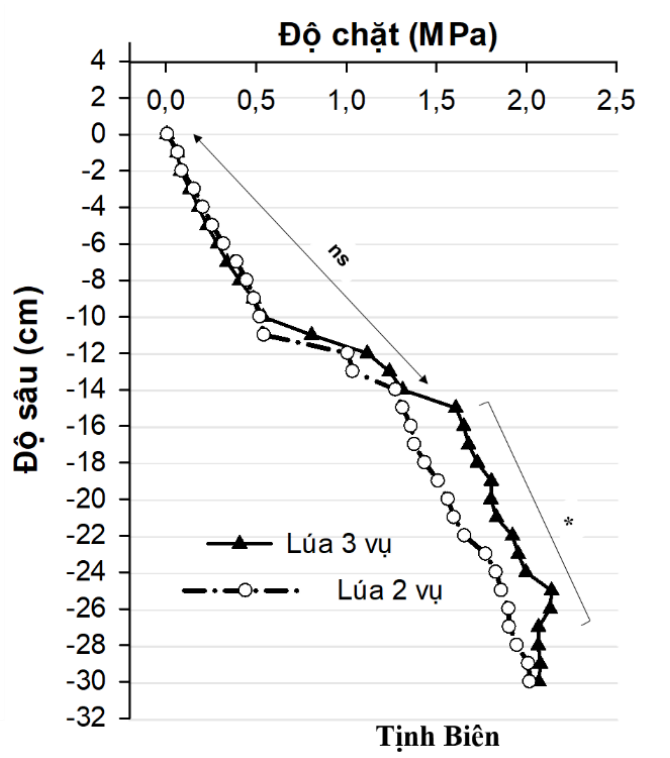

Hình 7. Độ chặt đất trong và ngoài đê bao tại Tri Tôn và Tịnh Biên

Ghi chú: "*” khác biệt có ý nghĩa thống kê mức 5\%, "ns" khác biệt không có ý nghĩa thống kê.

Theo thang đánh độ chặt đất của Cass et al. (1999), đất tầng $\mathrm{Bg}$ ở điểm nghiên cứu Tịnh Biên có độ chặt khá cao có thể làm cho rễ một số cây ngũ cốc bị ảnh hưởng. Kết quả nghiên cứu cho thấy độ chặt của đất trong đê cao hơn ngoài đê ở cả 2 điểm nghiên cứu đặc biệt ở tầng $\mathrm{Bg}$. Nguyên nhân do trong đê làm 3 vụ lúa/năm có nhiều lượt phương tiện máy cày, máy xới và máy cắt...di chuyển trên mặt ruộng nên làm cho tầng đế cày bị dẽ chặt hơn; trong khi đó đất ngoài đê sản xuất chỉ có 2 vụ/năm, phương tiện di chuyển trên mặt ruộng ít hơn. Kết quả độ chặt phản ánh phù hợp với các thông số dung trọng và độ xốp đất được thảo luận ở phần trên.

\subsubsection{Hệ số thấm bão hòa (Ksat)}

Kết quả nghiên cứu cho thấy tại Tri Tôn, hệ số thấm bão hòa (Ksat) trong và ngoài đê của tầng $\mathrm{Ap}$ lần lượt là $39,26.10^{-6} \mathrm{~m} / \mathrm{s}$ và $43,82.10^{-6} \mathrm{~m} / \mathrm{s}$, khác 
biệt không có ý nghĩa thống kê (p>0,05). Trong khi đó, Ksat tầng $\mathrm{Bg}$ trong và ngoài đê lần lượt là $0,45 \cdot 10^{-6} \mathrm{~m} / \mathrm{s}$ và $1,115 \cdot 10^{-6} \mathrm{~m} / \mathrm{s}$, khác biệt có ý nghĩa thống kê (Hình 8). Theo thang đánh giá của (O’Neal,
1949), hệ số thấm bão hòa tầng Ap trong và ngoài đê Tri Tôn ở mức nhanh, trong khi Ksat của tầng $\mathrm{Bg}$ được đánh giá ở mức rất chậm.

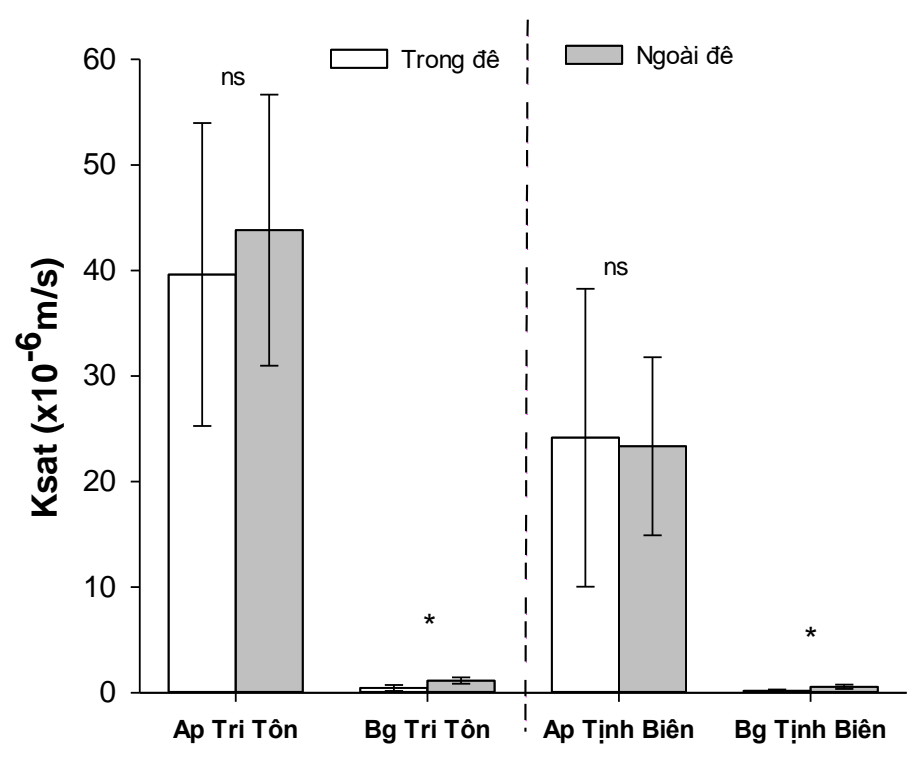

Hình 8. Hệ số thấm bão hòa (Ksat) đất trong và ngoài đê bao tại Tri Tôn và Tịnh Biên

Ghi chú: "*” khác biệt có ý nghĩa thống kê mức 5\%, "ns” khác biệt không có ý nghĩa thống kê.

Kết quả nghiên cứu tại Tịnh Biên cho thấy, hệ số thấm bão hòa (Ksat) ở tầng $\mathrm{Ap}$ trong và ngoài đê là $24,16 \cdot 10^{-6} \mathrm{~m} / \mathrm{s}$ và $23,34 \cdot 10^{-6} \mathrm{~m} / \mathrm{s}$, khác biệt không có ý nghĩa thống kê $(\mathrm{p}>0,05)$. So với thang đánh giá của (O'Neal, 1949) thì hệ số thấm bão hòa tầng Ap trong và ngoài đê Tịnh Biên đều ở mức khá nhanh. Trong khi đó, tầng $\mathrm{Bg}$ trong và ngoài đê lần lượt là $0,18 \cdot 10^{-6} \mathrm{~m} / \mathrm{s}$ và $0,56 \cdot 10^{-6} \mathrm{~m} / \mathrm{s}$ có sự khác biệt thống kê $(\mathrm{p}<0,05)$, tính thấm được đánh giá là rất chậm. Theo Nguyễn Thế Đặng và Nguyễn Thế Hùng (1999), độ thấm nước của đất $23.10^{-6} \mathrm{~m} / \mathrm{s}-35.10^{-6}$ $\mathrm{m} / \mathrm{s}$ (tương đương $2-3 \mathrm{~cm} /$ ngày) là tốt nhất. Tầng $\mathrm{Bg}$ của đất trong đê bao có hệ thấm thấp hơn đất ngoài đê ở cả hai điểm nghiên cứu. Điều này phù hợp với các thông số về sự nén dẽ được trình bày ở phần trên rằng đất tầng $\mathrm{Bg}$ nén dẽ hơn đất tầng $\mathrm{Ap}$ và đất trong đê có tầng $\mathrm{Bg}$ nén dẽ hơn đất ngoài đê.

\subsection{Tính chất hóa học đất trong và ngoài đê bao}

3.3.1. $p H$ đất

Kết quả nghiên cứu được trình bày ở Hình 9 cho thấy trị số $\mathrm{pH}$ tại Tri Tôn tầng 1 (Ap) trong đê có giá trị trung bình là 4,05 và ngoài đê là 5,$08 ; \mathrm{pH}$ trung bình tầng $2(\mathrm{Bg})$ trong đê là 3,85 và ngoài đê là 4,49 . Giá trị $\mathrm{pH}$ của cả 2 tầng đều có sự khác biệt có ý nghĩa thống kê ở mức 5\%. Kết quả tại Tịnh Biên cho thấy, trị số $\mathrm{pH}$ trung bình ở tầng $\mathrm{Ap}$ trong và ngoài đê lần lượt là 5,47 và 6,04 ; giá trị $\mathrm{pH}$ trung bình ở ngoài đê cao hơn trong đê và có sự khác biệt thống kê $(\mathrm{p}<0,05)$. Trị số $\mathrm{pH}$ ở tầng $\mathrm{Bg}$ trong đê có giá trị trung bình là 5,31 , ngoài đê là 5,89 , tương tự tầng $\mathrm{Ap}$ giá trị $\mathrm{pH}$ của tầng $\mathrm{Bg}$ ở ngoài đê cao hơn trong đê có ý nghĩa thống kê. Theo thang đánh giá, $\mathrm{pH}$ đất tại Tri Tôn được phân loại chua nhiều, $\mathrm{pH}$ đất tại Tịnh Biên chua đến chua vừa (Ngô Ngọc Hưng, 2009). 


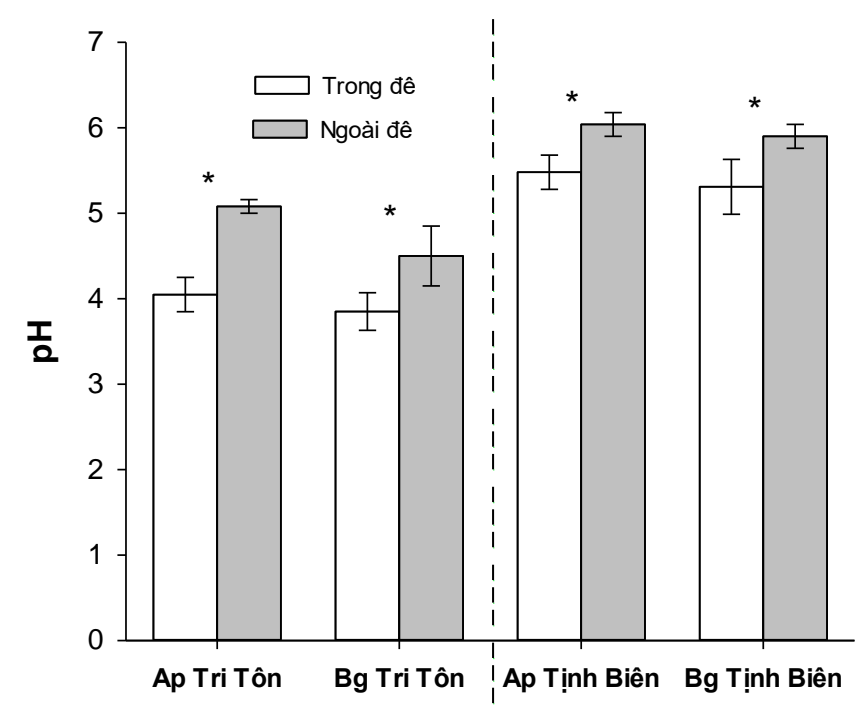

Hình 9. pH đất trong và ngoài đê bao theo tầng tại Tri Tôn và Tịnh Biên

Ghi chú: "*” khác biệt có ý nghĩa thống kê mức 5\%, "ns" khác biệt không có ý nghĩa thống kê.

Cả hai loại đất nghiên cứu đều có $\mathrm{pH}$ khu vực trong đê giảm thấp hơn ngoài đê và có khả năng ảnh hưởng không tốt đến sự phát triển cây lúa. Nguyên nhân có thể do canh tác 3 vụ lúa/năm đất bị tích tụ axit. Theo kết quả nghiên cứu của Phạm Quang Hà và Nguyễn Văn Bộ (2013), nếu thâm canh và sử dụng quá nhiều phân khoáng trong thời gian dài thì các quá trình chuyển hóa tạo ra các sản phẩm làm chua hóa đất. Trong khi đó, đất ngoài đê axit được rửa do nước lũ tràn đồng mỗi năm nên có $\mathrm{pH}$ cao hơn so với trong đê. Kết quả nghiên cứu này có khác biệt so với nghiên cứu của Nguyễn Hữu Chiếm và ctv. (2017) trên đất phù sa ở Châu Phú, Phú Tân, Chợ Mới và Thoại Sơn cho rằng trị số $\mathrm{pH}$ trung bình trong đê thấp hơn ngoài đê nhưng không khác biệt có ý nghĩa thống kê.

\subsection{2. Độ dẫn điện $E C$ đất}

Kết quả nghiên cứu (Hình 10) tại điểm nghiên cứu Tri Tôn cho thấy, trị số $\mathrm{EC}$ đất trung bình tầng Ap trong đê là $1,05 \mathrm{mS} / \mathrm{cm}$, ngoài đê là $0,71 \mathrm{mS} / \mathrm{cm}$. Trị số $\mathrm{EC}$ trung bình tầng $\mathrm{Bg}$ trong và ngoài đê bao lần lượt là $0,90 \mathrm{mS} / \mathrm{cm}$ và $0,63 \mathrm{mS} / \mathrm{cm}$. Trị số $\mathrm{EC}$ trung bình trong đê cao hơn ngoài đê và khác biệt có ý nghĩa thống kê ở cả 2 tầng đất. Nếu so sánh trong cùng hệ thống canh tác trong đê hoặc ngoài đê thì trị số $\mathrm{EC}$ ở tầng $\mathrm{Ap}$ có $\mathrm{xu}$ hướng cao hơn tầng $\mathrm{Bg}$ nhưng khác biệt không có ý nghĩa thống kê $(\mathrm{p}>0,05)$.

Kết quả nghiên cứu tại điểm nghiên cứu Tịnh Biên cho thấy giá trị EC tầng Ap trong đê bao cao hơn ngoài đê bao $(0,26 \mathrm{mS} / \mathrm{cm}$ so với $0,17 \mathrm{mS} / \mathrm{cm})$ và khác biệt có ý nghĩa thống kê $(\mathrm{p}<0,05)$. Tuy nhiên, tầng $\mathrm{Bg}$ có $\mathrm{EC}$ khác biệt không có ý nghĩa thống kê giữa mô hình canh tác trong đê và mô hình canh tác ngoài đê (Hình 10).

Đất ngoài đê canh tác 2 vụ lúa/năm, mỗi năm đều có nước lũ tràn đồng và có sự thoát nước sau mùa lũ, do đó các muối hòa tan trong đất bị rửa đi, nên $\mathrm{EC}$ ở ngoài đê luôn thấp hơn trong đê, việc rửa các muối hòa tan này đặc biệt có ý nghĩa đối với tầng đất mặt và vùng đất phèn. Giá trị $\mathrm{EC}$ trung bình trong và ngoài đê của Tri Tôn và Tịnh Biên lần lượt là 0,82 $\mathrm{mS} / \mathrm{cm}$ và $0,21 \mathrm{mS} / \mathrm{cm}, \mathrm{EC}$ tại Tri Tôn cao gấp 4 lần tại Tịnh Biên. Nguyên nhân là do trong đất phèn có chứa nhiều muối kim loại sắt và nhôm nên có độ dẫn điện cao hơn so với đất phù sa cổ. Tuy nhiên, EC của cả 2 nhóm đất nghiên cứu được đánh giá là không gây giới hạn năng suất cây trồng (Brady \& Weil, 2002; Ngô Ngọc Hưng, 2009). 


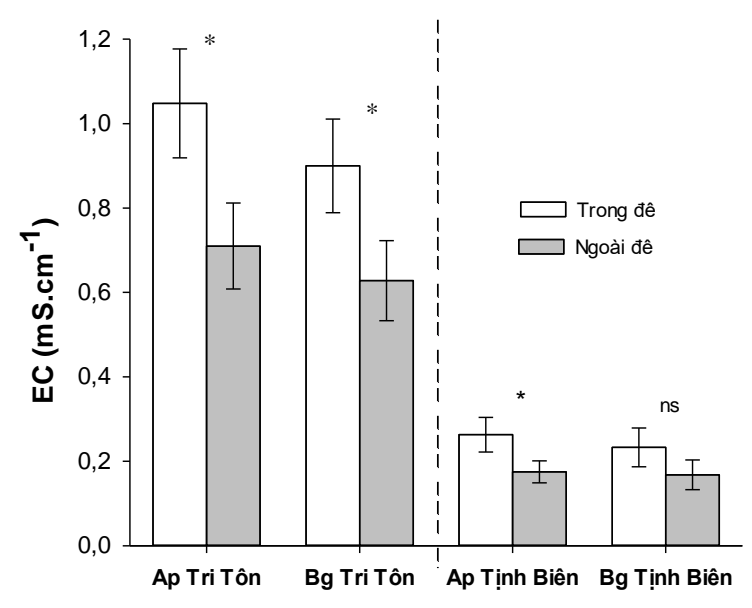

\section{Hình 10. EC đất trong và ngoài đê bao tại Tri Tôn và Tịnh Biên}

Ghi chú: "*” khác biệt có ý nghĩa thống kê mức 5\%, "ns" khác biệt không có ý nghĩa thống kê.

\subsubsection{Khả năng trao đổi cation của đất (CEC)}

Kết quả phân tích cho thấy đất tại điểm nghiên cứu Tri Tôn có giá trị CEC tầng Ap trong đê là 20,1 $\mathrm{cmol} / \mathrm{kg}$ cao hơn có ý nghĩa so với đất ngoài đê $(18,06 \mathrm{cmol} / \mathrm{kg})$. Trong khi ở tầng $\mathrm{Bg}$, trị số $\mathrm{CEC}$ trong và ngoài đê lần lượt là $16,30 \mathrm{cmol} / \mathrm{kg}$ và 16,72 $\mathrm{cmol} / \mathrm{kg}$, khác biệt không có ý nghĩa thống kê (Hình 11). Tại điểm nghiên cứu Tịnh Biên, tầng Ap có giá trị trung bình $\mathrm{CEC}$ trong đê $17,14 \mathrm{cmol} / \mathrm{kg}$ và ngoài đê là $15,32 \mathrm{cmol} / \mathrm{kg}$, có sự khác biệt thống kê giữa trong đê và ngoài đê $(\mathrm{p}<0,05)$. Tuy nhiên, $\mathrm{CEC}$ của tầng $\mathrm{Bg}$ khác biệt không có ý nghĩa thống kê giữa đất trong đê và ngoài đê.
Khả năng trao đổi cation trong các loại đất Việt Nam trong khoảng $5-30 \mathrm{cmol} / \mathrm{kg}$ dất, $\mathrm{CEC}$ càng cao thì đất càng phì nhiêu (Nguyễn Vy, 2003). Theo thang đánh giá, khả năng trao đổi cation (CEC) trong và ngoài đê cả 2 tầng tại Tri Tôn ở mức cao, còn tại Tịnh Biên CEC trong và ngoài đê cả 2 tầng đều ở mức độ trung bình (Brady \& Weil, 2002; Ngô Ngọc Hưng, 2009). Theo Marx et al. (1999), CEC của đất tùy thuộc vào sa cấu và hàm lượng hữu cơ. Kết quả tại 2 điểm nghiên cứu cho thấy CEC có liên quan đến hàm lượng chất hữu cơ trong đất, hàm lượng chất hữu cơ tầng mặt của đất trong đê bao cao hơn (Hình 12) nên có CEC cao hơn so với đất ngoài đê bao ở cả 2 điểm nghiên cứu.

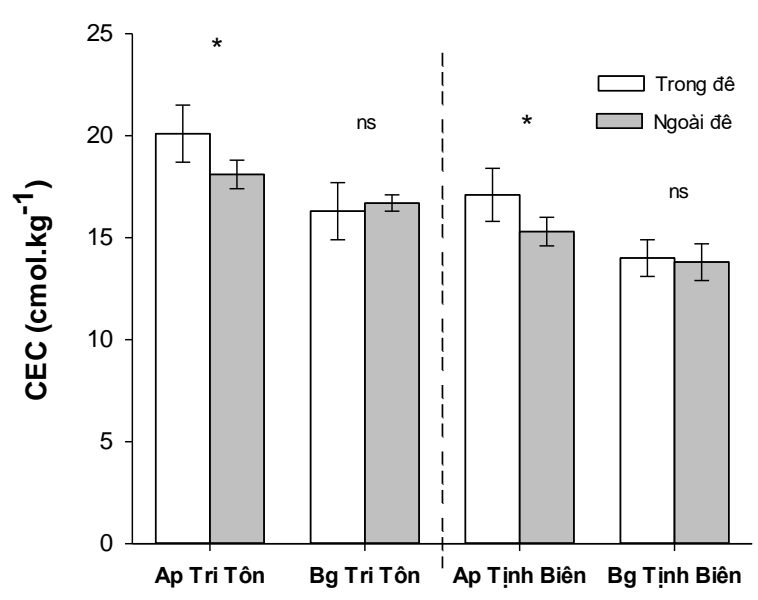

Hình 11. CEC đất trong và ngoài đê bao tại Tri Tôn và Tịnh Biên

Ghi chú: "*” khác biệt có ý nghĩa thống kê mức 5\%, "ns" khác biệt không có ý nghĩa thống kê. 


\subsubsection{Hàm lương chất hũu cơ của đất $(\mathrm{CHC})$}

Kết quả phân tích tại Tri Tôn cho thấy, hàm lượng chất hữu cơ ở tầng $\mathrm{Ap} \mathrm{khu} \mathrm{vực} \mathrm{trong} \mathrm{đê} \mathrm{bao}$ $(7,27 \%)$ cao hơn so với đất ngoài đê bao $(6,24 \%)$ và khác biệt có ý nghĩa thống kê $(\mathrm{p}<0,05)$, trong khi đó $\mathrm{CHC}$ tầng $\mathrm{Bg}$ trong và ngoài đê bao có giá trị lần lượt là $4,07 \%$ và $4,00 \%$ khác biệt không có ý nghĩa thống kê (p>0,05) (Hình 12).

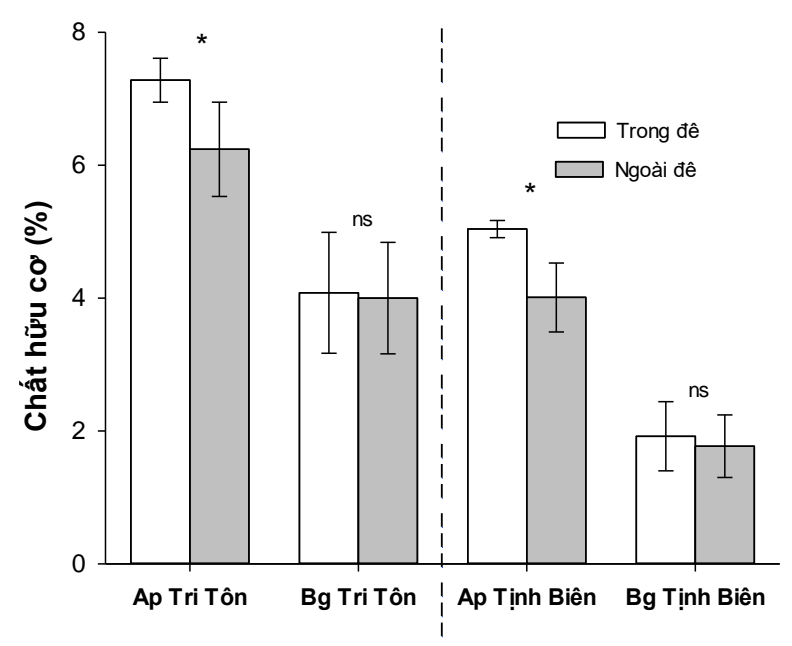

Hình 12. Hàm lượng chất hữu cơ đất trong và ngoài đê bao tại Tri Tôn và Tịnh Biên

Ghi chú: “*” khác biệt có ý nghĩa thống kê mưc 5\%, "ns” khác biệt không có ý nghĩa thống kê.

Tương tự với điểm Tri Tôn, hàm lượng chất hữu cơ của điểm nghiên cứu Tịnh Biên khác biệt có ý nghĩa thống kê theo hướng $\mathrm{CHC}$ trong đê cao hơn $\mathrm{CHC}$ ngoài đê. Hàm lượng $\mathrm{CHC}$ tầng $\mathrm{Bg}$ không có sự khác biệt thống kê giữa trong đê và ngoài đê. Điều này có thể được giải thích là do khu vực trong đê có quá trình canh tác lúa liên tục 3 vụ/năm, gốc rạ thường xuyên được cày vùi vào trong đất vì vậy làm tăng hàm lượng chất hữu cơ trong đất ở vùng trong đê bao khép kín so với mô hình canh tác 2 vụ lúa/năm ở khu vực ngoài đê. Kết quả của nghiên cứu này tương đồng với kết quả nghiên cứu của Nguyễn Hữu Chiểm và ctv. (2017) trên nhóm đất phù sa rằng chất hữu cơ của đất trong đê luôn cao hơn trong đất ngoài đê.

Ở cả 2 điểm nghiên cứu Tri Tôn và Tịnh Biên, hàm lượng chất hữu cơ tầng $\mathrm{Ap}$ luôn cao hơn và khác biệt có ý nghĩa thống kê so với $\mathrm{CHC}$ tầng $\mathrm{Bg}$ là do gốc rạ sau thu hoạch được cày vùi tập trung ở tầng đất mặt.

\subsection{5. Đạm tổng số (Nts) của đất}

Kết quả phân tích tầng đất Ap tại Tri Tôn cho thấy đạm tổng số ở vùng trong đê bao cao hơn vùng ngoài đê và có sự khác biệt thống kê $(p<0,05)$, điều này có thể do tổng lượng phân bón trong đê (trong đó có phân đạm) nhiều hơn ngoài đê và hàm lượng chất hữu cơ của đất trong đê luôn cao hơn đất ngoài đê (Hình 13). Ở tầng $\mathrm{Bg}$, đạm tổng số trong đê là $0,21 \%$ thấp hơn ngoài đê $0,22 \%$, tuy nhiên khác biệt không có ý nghĩa thống kê. Điều này được giải thích là do tầng $\mathrm{Bg}$ là tầng đế cày ít bị tác động bởi phân bón và xác bả thực vật để lại trên ruộng, nên hàm lượng đạm tổng số thấp so với tầng mặt $\mathrm{Ap}$ và ít bị thay đổi giữa mô hình canh tác trong đề và ngoài đê.

Kết quả thống kê (Hình 13) tại Tịnh Biên cho thấy hàm lượng đạm tổng số trung bình trong và ngoài đê ở cả 2 tầng dao động từ 0,09 đến $0,26 \%$, không có sự khác biệt thống kê $(\mathrm{p}>0,05)$, so với thang đánh giá của Metson (1961) thì hàm lượng đạm tổng số có trong đất ở mức độ từ rất thấp đến trung bình. 


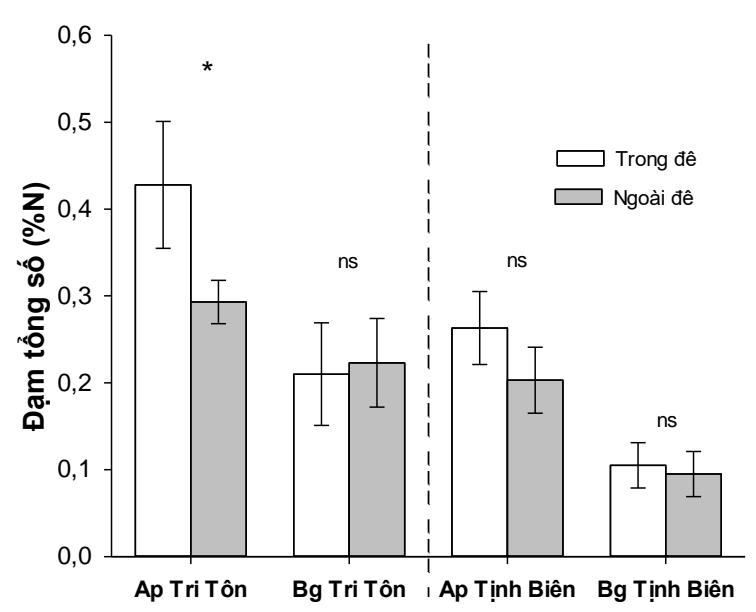

Hình 13. Đạm tổng số (Nts) đất trong và ngoài đê bao tại Tri Tôn và Tịnh Biên

Ghi chú: “*” khác biệt có ý nghĩa thống kê mức 5\%, "ns" khác biệt không có ý nghĩa thống kê.

Khi so sánh giữa 2 tầng đất $\mathrm{Ap}$ và $\mathrm{Bg}$ trong cùng hệ thống canh tác trong đê hoặc ngoài đê thì đạm tổng số của tầng Ap luôn cao hơn có ý nghĩa thống kê so với tầng $\mathrm{Bg}$ trên cả 2 nhóm đất nghiên cứu. Điều này được giải thích là do lượng đạm trong đất phụ thuộc vào hàm lượng và chất lượng chất hữu cơ trong đất, hầu hết đạm trong đất ở dạng đạm hữu cơ, do đó hàm lượng chất hữu cơ trong đất cao thường đi đôi với giàu đạm tổng số trong đất (Đỗ Thị Thanh Ren, 1999; Võ Thị Gương và ctv., 2010). Theo tập quán canh tác của nông dân, rơm rạ trong quá trình canh tác chỉ được vùi và tích lũy ở tầng mặt $\mathrm{Ap}(0$ $15 \mathrm{~cm})$, vì vậy tầng mặt có hàm lượng chất hữu cơ cao hơn nên đạm tổng số tầng mặt cao hơn so với tầng đất bên dưới.

\subsubsection{Lân tổng số $\left(\% \mathrm{P}_{2} \mathrm{O}_{5}\right)$ trong đất}

Kết quả phân tích được trình bày ở Hình 14 cho thấy đất tại Tri Tôn có hàm lượng lân tổng số tầng Ap ở trong đê là $0,23 \% \mathrm{P}_{2} \mathrm{O}_{5}$, ngoài đê là $0,18 \% \mathrm{P}_{2} \mathrm{O}_{5}$; ở tầng $\mathrm{Bg}$, lân tổng số trong đê là $0,12 \% \mathrm{P}_{2} \mathrm{O}_{5}$ và ngoài đê $0,14 \% \mathrm{P}_{2} \mathrm{O}_{5}$; tuy nhiên khác biệt không có ý nghĩa thống kê ở cả 2 tầng.

Đối với đất Tịnh Biên, hàm lượng lân tổng số ở tầng $\mathrm{Ap}$ trong và ngoài đê bao có giá trị lần lượt là $0,12 \% \mathrm{P}_{2} \mathrm{O}_{5}$ và $0,09 \% \mathrm{P}_{2} \mathrm{O}_{5}$ nhưng khác biệt không có ý nghĩa thống kê. Tương tự đối với tầng $\mathrm{Bg}$, lân tổng số cũng không khác biệt thống kê giữa đất trong đê và ngoài đê (Hình 14).

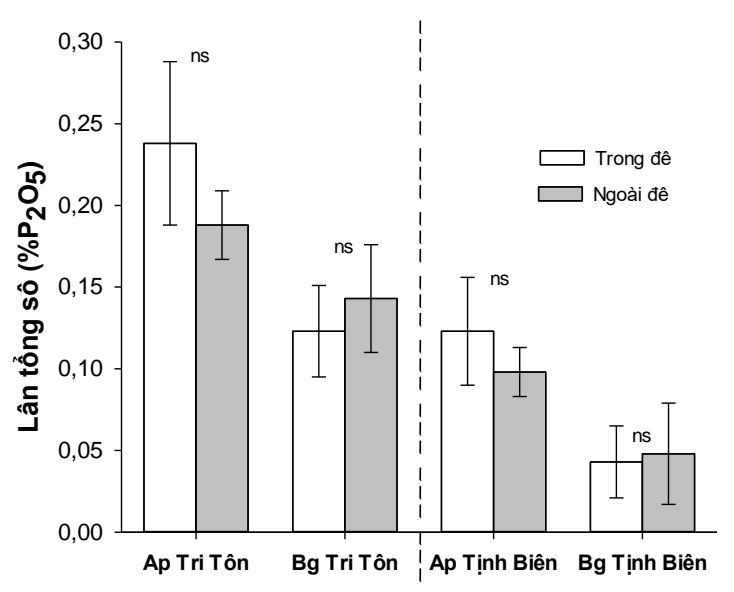

Hình 14. Lân tổng số $\left(\% \mathrm{P}_{2} \mathrm{O}_{5}\right)$ đất trong và ngoài đê bao tại Tri Tôn và Tịnh Biên

Ghi chú: "*” khác biệt có ý nghĩa thống kê mức 5\%, "ns" khác biệt không có ý nghĩa thống kê. 
Ở cả 2 nhóm đất nghiên cứu, hàm lượng lân tổng số trong đê giữa tầng $\mathrm{Ap}$ và tầng $\mathrm{Bg}$ có sự khác biệt thống kê $(\mathrm{p}<0,05)$. Theo thang đánh giá lân tổng số của Lê Văn Căn (1985) tại Tri Tôn, đất tầng Ap giàu lân, tầng $\mathrm{Bg}$ hàm lượng lân ở mức khá đến giàu. Trong khi đó, tại Tịnh Biên, lân tổng số trong và ngoài đê ở tầng $\mathrm{Ap}$ ở mức khá, còn ở tầng $\mathrm{Bg}$ chỉ ở mức độ nghèo lân. Sự chênh lệch hàm lượng lân trong đất giữa tầng $\mathrm{Ap}$ và tầng $\mathrm{Bg}$ có thể do đặc điểm chậm tan của phân lân, khi bón vào đất lân di chuyển kém và khó bị rửa trôi từ tầng đất mặt xuống tầng đất bên dưới. Nếu bón liên tục phân lân vô cơ thì hàm lượng lân tổng số trong tầng canh tác sẽ tăng lên (Ngô Thị Đào và Vũ Hữu Yêm, 2007).

\subsubsection{Kali tổng số trong đất $\left(\% \mathrm{~K}_{2} \mathrm{O}\right)$}

Kết quả phân tích đất tầng $\mathrm{Ap}$ và $\mathrm{Bg}$ tại Tri Tôn và Tịnh Biên cho thấy hàm lượng Kali tổng số đều khác biệt không có ý nghĩa thống kê giữa đất trong đê và ngoài đê (Hình 15). Theo thang đánh giá kali tổng số trong đất của Kyuma (2004), hàm lượng kali trong và ngoài đê của tầng $\mathrm{Ap}$ ở mức khá và tầng $\mathrm{Bg}$ ở mức trung bình đối với điểm nghiên cứu Tri Tôn; hàm lượng kali trong và ngoài đê của tầng $\mathrm{Ap}$ ở mức trung bình, tầng $\mathrm{Bg}$ ở mức nghèo đối với điểm nghiên cứu Tịnh Biên. Điều này cho thấy sự cung cấp kali là cần thiết để đảm bảo sự cân bằng dinh dưỡng cho đất, tránh trường hợp suy thoái kali trong đất, đưa đến việc giảm năng suất và phẩm chất cây trồng. Trước đây, nhiều thí nghiệm về kali có kết luận chung là đất Đồng bằng sông Cửu Long không thiếu kali và hiệu lực phân kali rất thấp hoặc không thể hiện rõ nên không cần bón kali (Công Doãn Sắt, 1994). Điều này có thể đúng vì trước đây chỉ canh tác một vụ lúa trong năm; ngày nay đất thường được thâm canh tăng vụ trồng 2 vụ hoặc 3 vụ lúa/năm và đất không được phù sa bồi đẳp hẳng năm nên có thể làm dinh dưỡng ngày càng cạn kiệt, trong đó có kali.

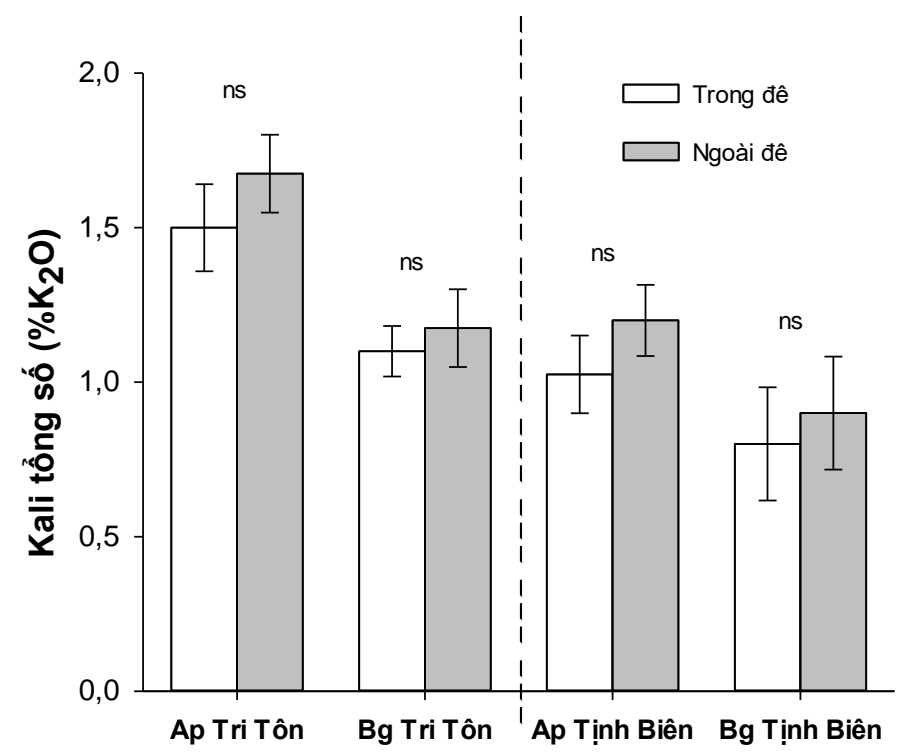

Hình 15. Kali tổng số $\left(\% \mathrm{~K}_{2} \mathrm{O}\right)$ đất trong và ngoài đê bao tại Tri Tôn và Tịnh Biên

Ghi chú: “*” khác biệt có ý nghia thống kê mức 5\%, "ns" khác biệt không có ý nghia thống kê.

\section{KẾT LUẬN}

Đê bao ảnh hưởng đến đặc tính lý hóa đất tầng mặt $\mathrm{Ap}$ và tầng ngay dưới tầng mặt $\mathrm{Bg}$. Đất tầng $\mathrm{Bg}$ có độ nén dẽ luôn cao hơn ở đất trong đê so với đất ngoài đê ở cả hai nhóm đất nghiên cứu khác nhau Tri Tôn và Tịnh Biên thể hiện qua độ xốp, dung trọng và độ chặt cao từ đó dẫn đến hệ số thấm thấp. Trong khi đó, tầng mặt đất xốp và khác biệt không có ý nghĩa thống kê giữa nhóm đất trong đê và ngoài đê.

Canh tác 3 vụ lúa/năm trong vùng đê bao ở cả hai khu vực nghiên cứu Tri Tôn và Tịnh Biên đã làm tích tụ axit và các muối hòa tan trong đất cao hơn so với ngoài đê, thể hiện ở $\mathrm{pH}$ đất trong đê thấp hơn so với $\mathrm{pH}$ đất ngoài đê, $\mathrm{EC}$ của đất trong đê cao hơn so với $\mathrm{EC}$ của đất ngoài đê; điều này thể hiện rõ ở nhóm đất phèn. 
Cả 2 nhóm đất phèn Tri Tôn và đất phù sa cổ ở Tịnh Biên có hàm lượng chất hữu cơ tầng mặt trong đê (3 vụ lúa/năm) cao hơn so với đất ngoài đê ( 2 vụ lúa/năm) do lượng gốc rạ được vùi vào đất nhiều hơn ở đất lúa 3 vụ canh tác trong đê; từ đó dẫn đến khả năng trao đồi cation (CEC), đạm tổng số của đất trong đê cũng cao hơn so với đất ngoài đê, đặc biệt ở tầng đất mặt $\mathrm{Ap}$. Trong khi đó, hàm lượng lân tổng số và kali tổng số chưa thấy được sự khác biệt có ý nghĩa thống kê ở cả hai nhóm đất nghiên cứu.

\section{LỜI CẢM TẠ}

Đề tài này được tài trợ bởi Dự án Nâng cấp trường Đại học Cần Thơ VN14-P6 bằng nguồn vốn vay ODA từ chính phủ Nhật Bản.

\section{TÀI LIẸU THAM KHẢO}

Bộ môn Khoa học đất, Trường Đại học Cần Thơ. (2015). Bản đồ đất Đồng bằng sông Củu Long.

Brady, N.C., \& Weil, R.R. (2002). The nature and properties of soils, $13^{\text {th }}$ ed., Prentice Hall, New Jersey, USA, 960.

Cass, A. (1999). Interpretation of some soil physical indicators for assessing soil physical fertility. In 'Soil analysis: An interpretation manual'. (Eds. Peverill, K.I., Sparrow, L.A., Reuter, D.J.). CSIRO Publishing, Melbourne, 95-102.

Công Doãn Sắt. (1994). Hiệu lực của phân kali đối với một số cây luơng thực và thực phẩm ở miền Đông Nam Bộ và đồng bằng sông Cửu Long. Tuyển tập công trình nghiên cứu khoa học kỹ thuật nông nghiệp. Nhà xuất bản Nông nghiệp.

Dương Hồng Gấm. (2015). Đánh giá chất luợng đất và phù sa trong và ngoài đê bao ở Chơ Mói và Phú Tân tỉnh An Giang. Luận văn cao học. Trường Đại học Cần Thơ.

Dương Quỳnh Thanh, Trần Thị Lệ Hằng, Phạm Hữu Phát \& Văn Phạm Đăng Trí. (2017). Phân tích một số khía cạnh kinh tế và môi trường của các mồ hình sản xuất nông nghiệp trong vùng đê bao khép kín, trường hợp nghiên cứu tại huyện Chợ Mới, tỉnh An Giang. Tap chi Khoa hoc Truòng Đại học Cần Tho: Số chuyen đề: Mồi truờng và Biến đổi khi hậu (1), 110-119.

Đỗ Thị Thanh Ren. (1999). Bài giảng phì nhiêu đất và phân bón. Trường Đại học Cần Thơ.

Kyuma K. (2004). Paddy Soil Science. Kyoto University Press.

Le, T.V.H., Nguyen, H.N., Eric, W., Tran, T.C., \& Haruyama, S. (2006). Combine impact on the flooding in Vietnam's Mekong Delta of local man-made structures, sea level rise, and dams upstream in the river catchment. Estuar. Coast. Shelf Sci. 71, 110-116.
Lê Văn Căn. (1985). Sủ dụng phân lân miền Nam Việt Nam. Nhà xuất bản Nông nghiệp.

Lê Văn Khoa. (2003). Sự nén dẽ trong đất trồng lúa thâm canh ở Đồng bằng sông Cửu Long, Việt Nam. Tạp chi khoa hoc Đại hoc Cần Tho, chuyên ngành Khoa học Đất và Quản lý Đất đai, 93-101.

Lipiec, J. \& Stepniewski, W. (1995). Effects of soil compaction and tillage systems on uptake and losses of nutrients. Soil Tillage Research, 35(12), 37-52.

Marx, E.S., Hart, J. \& Stevens, R.G. (1999). Soil Test Interpretation Guide. Oregon State University Extension Service Publication: EC 1478.

Metson, A.J. (1961). Methods of chemical analysis for soil survey samples. Soil Bulletin, 12 GVT Printer Wellington, DSIR, New Zealand.

Mohr, E.C.J., van Baren F.A., \& van Schuylenborgh J. (1972). Tropical soils. A comprehensive study of their genesis. Mouton, The Hague.

Ngô Ngọc Hưng. (2009). Tính chất tụ nhiên và nhũng tiến trình làm thay đổi độ phì nhiêu đất Đồng bằng sông Củu Long. NXB Nông Nghiệp. TP. Hồ Chí Minh.

Ngô Thị Đào \& Vũ Hữu Yêm. (2007). Đất và phân bón. Nhà xuất bản Đại học Sư phạm Hà Nội.

Nguyễn Hữu Chiếm \& Huỳnh Công Khánh. (2016). Đánh giá động thái dinh dưỡng - độ phì của đất và ảnh hưởng của việc kiểm soát lũ lên sức sản xuất của đất trong vùng đê bao khép kín. Báo cáo Chuyên đề thuộc đề tài cấp tỉnh. Đánh giá tác động hệ thống kiểm soát lũ đối với sức sản xuất của đất, khả năng chịu tải của nguồn nuoớc và súc khỏe cộng đồng phục vu phát triển nông nghiệp bền vũng. Sở Khoa học và Công nghệ tỉnh An Giang.

Nguyễn Hữu Chiếm, Huỳnh Công Khánh, Nguyễn Xuân Lộc \& Đinh Thị Việt Huỳnh (2017). Đánh giá và so sánh tính chất lý-hóa học đất trồng lúa trong và ngoài đê bao khép kín tỉnh An Giang. Tạp chi Khoa hoc Truòng Đại hoc Cần Tho: Số chuyên đề: Môi trương và Biến đổi khí hậu (1), 86-92.

Nguyễn Thế Đặng \& Nguyễn Thế Hùng. (1999). Giáo trình đất. NXB Nông nghiệp, Hà Nội.

Nguyễn Vy. (2003). Độ phì nhiêu thực tế. Nhà xuất bản Nghệ An.

Nguyễn Xuân Thịnh, Trương Thanh Tân, Trần Thị Lệ Hằng \& Văn Phạm Đăng Trí. (2016). Đánh giá tổng hợp hiệu quả dự án kiểm soát lũ Đồng bằng sông Cửu Long - vùng nghiên cứu Nam Vàm Nao. Tạp chi Khoa học Công nghệ Nông nghiệp Việt Nam, 5(66), 95 - 102.

O’Neal, A.M. (1949). Soil characteristics significance in evaluating permeability. Soil Science, 67, 403-409. 
Phạm Lê Mỹ Duyên \& Văn Phạm Đăng Trí. (2015). Chất lượng nước mặt và khả năng tự làm sạch của hệ thống kênh trong vùng đê bao khép kín ở Thị Trấn Mỹ Luông, huyện Chợ Mới, tỉnh An Giang. Tạp Chí khoa học Đại học Cần Tho, 36, $18-26$.

Phạm Ngọc Xuân. (2004). Chất lự̛ng môi truoòng đất ở các vùng đê bao kiểm soát lũ thuộc huyện An Phú và Chơ Mới - tỉnh An Giang. Luận án thạc sĩ. Đại học Cần Thơ.

Phạm Quang Hà \& Nguyễn Văn Bộ. (2013). Sử dụng phân bón trong mối quan hệ với sản xuất lương thực, bảo vệ môi trường và giảm phát thải khí nhà kính. Tạp chí Nông nghiẹp \& PTNT, 3, 41-46.

Swan, J. B., Moncrief J. F., \& Voorhees, W. B. (1999). Soil compaction: causes, effects and control. BU-3115-GO review 1994. Extension service. University of Minnesota.

Trần Thành Lập. (1999). Phì nhiêu đất. Bài giảng phì nhiêu đất và phân bón. Trường Đại học Cần Thơ.

United States Department of Agriculture, Soil Conservation Service (USDA/SCS). (1984). Soil survey laboratory methods and procedures for collecting soil samples. Soil Survey Investigations Report No. 1. U.S. Government Printing Office, Washington, DC.

Viện Thổ nhưỡng Nông hóa. (2009). Sổ tay phân tích đất-nước phân bón và cây trồng. Nhà xuất bản nông nghiệp Hà Nội.

Võ Thị Gương, Dương Minh Viễn \& Nguyễn Minh Đông. (2010). Cải thiện độ phì nhiêu đất và năng suất lúa canh tác ba vu trong đê bao ở đồng bằng sông Cửu Long. NXB Nông nghiệp TP. Hồ Chí Minh. 